\title{
Reviewing Appropriate Game Design Elements for Mobile Augmented Reality Games
}

Fasehah Abdullah, Azhar Abd. Jamil

To Link this Article: http://dx.doi.org/10.6007/IJARBSS/v11-i2/9178

DOI:10.6007/IJARBSS/v11-i2/9178

Received: 11 December 2020, Revised: 09 January 2021, Accepted: 18 January 2021

Published Online: 20 February 2021

In-Text Citation: (Abdullah \& Jamil, 2021)

To Cite this Article: Abdullah, F., \& Jamil, A. A. (2021). Reviewing Appropriate Game Design Elements for Mobile Augmented Reality Games. International Journal of Academic Research in Business and Social Sciences, 11(2), 882-891.

\section{Copyright: @ 2021 The Author(s)}

Published by Human Resource Management Academic Research Society (www.hrmars.com)

This article is published under the Creative Commons Attribution (CC BY 4.0) license. Anyone may reproduce, distribute, translate and create derivative works of this article (for both commercial and non-commercial purposes), subject to full attribution to the original publication and authors. The full terms of this license may be seen at: http://creativecommons.org/licences/by/4.0/legalcode

Vol. 11, No. 2, 2021, Pg. 882 - 891

Full Terms \& Conditions of access and use can be found at http://hrmars.com/index.php/pages/detail/publication-ethics 


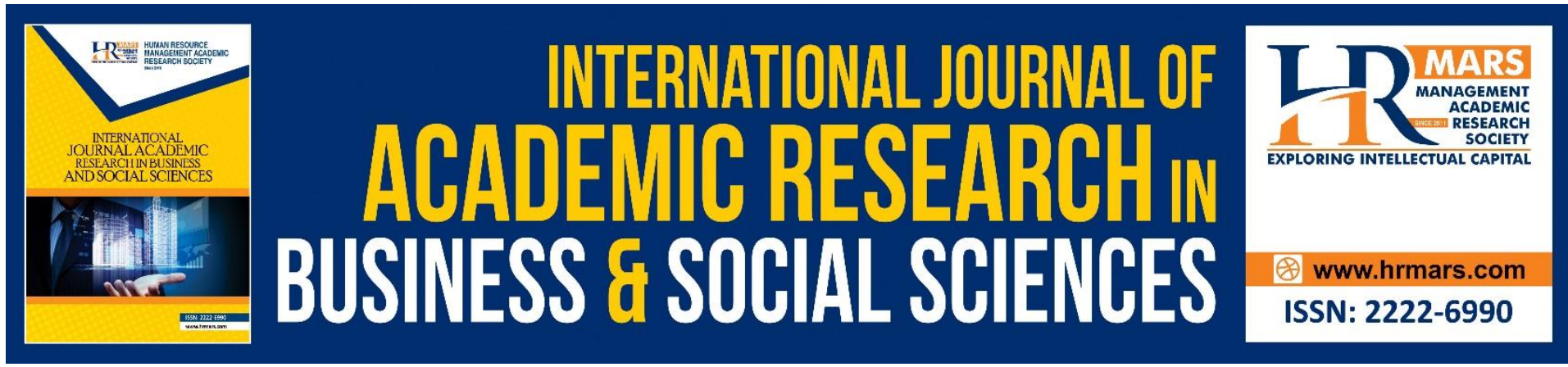

\title{
Reviewing Appropriate Game Design Elements for Mobile Augmented Reality Games
}

\author{
Fasehah Abdullah, Azhar Abd. Jamil \\ Faculty of Arts and Design, Southern University College, Faculty of Arts and Design, UiTM \\ Shah Alam, Malaysia
}

\begin{abstract}
Mobile Augmented Reality (MAR) are increasing and now becoming a trend. New trending investment in augmented reality and virtual reality keep growing rapidly. The purpose of this paper is to give information and reviews for MAR game's company, AR game designers or educators to follow appropriate game design elements in creating mobile augmented reality game's design. This paper concludes that the current trends of MAR games and reviews can measure the appropriate mobile augmented reality game's elements in creating interface design.
\end{abstract}

Keywords: Mobile Augmented Reality, Game Design, and Elements.

\section{Introduction}

Mobile augmented reality games technology become worldwide heading after the release of the trending MAR games Pokemon GO and became the leading game application labels worldwide. (Augmented Reality Statistic and Facts, 2018). Augmented reality overlay with elements like 3D model objects, text information or multimedia elements onto real world images (Hsieh \& Lin, 2011). According to Perkins (2018), from the survey shows huge majority of professional respondents assume developers to emphasis their efforts over the next year on producing AR applications and tools for smartphones (82\%) and gaming maintained the segment projected to attract the most AR or VR-related investment. However, less is acknowledged on how to implement game design patterns to augmented reality (Antonaci et al., 2015). There is no specific guidelines or appropriate elements guideline when creating mobile augmented reality games design interface. This paper emphasis on game design elements and focus is to guide the MAR game's company, AR game designers and educators to use appropriate elements in creating interface design. Firstly, this paper exhibits the basic elements of mobile augmented reality (Section 2) as the basis of my current PhD research. Secondly, design development of appropriate games design elements for mobile augmented reality (Section 3) to find gaps between this game design elements. Lastly, his paper will have the conclusion and future work.

\section{Basic Elements of Mobile Augmented Reality}

Mobile Augmented Reality (MAR) is known as a type of Augmented Reality that use mobile devices such as smartphone or tablet. Augmented reality enhances graphic design, motion, 
sounds, and real world. Both smartphones and video games are under the development of augmented reality, p.3. (Dirin et al. 2018). Furthermore, Augmented Reality is not only limited to visual or graphic design interfaces but also infrequently include audio or voice command, and haptic interfaces (Dunser et al. 2007). Voice command, hand gestures to control virtual buttons for MAR objects, and movement gestures are examples of new GUI components that can relate to MAR applications. This section 2 lists the 12 basic elements of mobile augmented reality based on existing research about MAR games. 12 MAR elements such as 2D graphic design, 3D graphic design, 2D animation, 3D animation, text, image, recording, audio / sound, voice commands, video, haptic feedback, and interactive maps (GPS location).

Image (2D graphic design / 3D graphic design)

Images and graphics produced by the computer in variety of types such as 2D graphic design and 3D graphic design (illustration, cartoons / game character and others), bitmap images, photography, and vector images. In the bitmap images, it needs the number of pixels to create appropriate width, height, and colour depth. However, vector images are created from drawing elements such as shape, circles, form, value, line, perspective, space, rectangles, colour, and texture to create object or image. Image formats used for vector images are JPEG, GIF, PNG, and TIFF.

Animation (2D animation / 3D animation)

Animation contained images showed so fast and continuous movement. Two basic types of animations are frame animation and path animation. Two-dimensional animation animates still images by the flat $X$ and $Y$ axis in the screen. Meanwhile, three-dimensional animation have three axis to show the images from all the viewpoints such as $X, Y$, and $Z$ (depth) axis.

Text

Text is the common way to give the information and basic elements in multimedia. In multimedia, there are two types of text used which are static text and hypertext. Static text fit well in the graphics design for explanation (textual information) and is easy to read. While hypertext or hyperlinked media, includes the text and links that provides the flexibility of choice for user to navigate the material.

Sound / Audio / Recording / Voice commands

Sound, audio, recording, and voice commands are all inside the multimedia system. Sound or audio are deep element for special effects for mood background setting. Sound sampling (sample size, bit depth, and resolution) is stored as a digital information. Then, the digital recording is the sound recorded on an audio by using microphone or other devices in an analogue format which then converted to digital format (sound sampling) to be stored. Next, voice commands systems are the hands-free interaction with the device, and it has noise cancelling microphone to recognize user voice. This voice commands systems can trigger basic command for menu such as open, play, save, mute, and other commands.

Video

Videos are motion picture, the recorded real events and displayed on the screen, as an advertisement and the sources to convey information. The player can control the video through fast forward buttons, start, stop, and rewind. 
Haptic feedback

Haptic feedback is guide movement from the touch from hand or body gestures. The feedback is the reaction from the game after the player made choices or changes and give information related with the decision that was taken from the player and effecting the game, (Cavalcanti et. al., 2019).

Interactive maps (GPS location)

Interactive maps or global positioning system (GPS) is the current element used in mapping routes and current position for player in the game. If the position of all cameras in both virtual and physical can detect movements, at that point digital objects (hidden object) can be rendered and pop up in the display. Inside AR games, the pose of the camera ( $x, y, z, p i t c h$, roll) can detect how good the players interact with the avatar (game characters), (Eishita, et. al. 2018).

\section{Game Design Elements for Mobile Augmented Reality}

According to Noor et al. (2015), the previous research in AR games also implemented game design elements but there are not many discussions about the important aspects in gamification platform such as reward system including badges, points, and others. Other researchers also list the same game design elements such as levels, quests, achievement, avatars, challenges, leader boards and others. In section 3, 13 game design elements of mobile augmented reality are listed based on existing research about MAR games. The 13 games design elements for MAR are avatar, task or quest, hints, levels, points or coins, leaderboards badges, navigate location, score, time, digital object (hidden object), rewards, achievement, and narrative storytelling.

Rewards, achievement or goals, points, score, coins, levels, and leaderboards badges.

Rewards element are related with the player's achievement in specific skills and challenges. The rewards are basically in the form badges, extra powers, medals, and others, (Ferreira-Brito et. al., 2019). Meanwhile, the score elements in a game system is intended to notify player about their level progression in the game, with more points means more successful. Basically, the reward points are in the form of points, coins or money, levels, life bar, and leaderboards. Leaderboards are based on competition among player in one game. For example, when the only first player to achieve a goal will get badge reward, (Broer, 2017).

Mission and time (task, quest, and hints)

Missions in games encourage the player to explore and challenge themselves to achieve specific task, quest, or hints. This is different for score, point, badges, and others that make player interested in collecting something (Wee \& Choong, 2019). Meanwhile, time limit in game play will give player pressure of time control to achieve the highest score possible or complete a quest or task. For example, life bar in game's score element, the player will lose score every time if they do not complete the game's task (Filipa et. al., 2019).

\section{Avatar}

The avatar creation and digital personas in the game with multiple basic function represent the gamer. Avatar creation in fantasy world enables the player to choose their role-play with variety identities, appearance (skin colour, hair, height, and others), and traits like leadership, confidence, and others (Stavropoulos et. al., 2020). 
Navigate Location

Navigate location system in mobile augmented reality become a popular element after Pokemon Go hit the game's market. This navigation system can detect the current position of the player in the game with global positioning system (GPS) and it is used in mapping routes. The mapping routes are to detect digital objects (hidden object) that can be rendered and pop out on player's mobile screen.

Digital object (hidden object)

Haptic Interaction Point (HIP) device will interact with digital object or hidden object when the player's current position is in point-based haptic (Kaklanis et. al., 2013). Hidden objects are considered as valuable items that player need to collect and achieve. These hidden objects will appear on player's screen when they reach a specific place.

Narrative storytelling

Narrative storytelling in digital platforms can convey important information to player through stories and get the players to interact. The main outcomes of storytelling in games are it can increase players' knowledge and give more impacts to the players. (Gomez et. al., 2019). Narrative storytelling basically consists of plot, dialogues, characters, theme, and others.

\section{Basic Elements and Games Design Elements for Mobile Augmented Reality}

This paper empirically analysed basic elements of mobile augmented reality and games design elements for mobile augmented reality. It studied the existing MAR games available in the digital market based on discussion from previous literature review.

Table 1. Examples of Previous Research in AR Games

\begin{tabular}{|c|c|c|c|c|}
\hline No & Researchers & AR Games & AR Elements & $\begin{array}{c}\text { Game Design } \\
\text { Elements }\end{array}$ \\
\hline \multirow[t]{4}{*}{1.} & \multirow[t]{4}{*}{$\begin{array}{l}\text { Liberati, } \\
\text { (2018) }\end{array}$} & $\begin{array}{l}\text { Pokemon Go by } \\
\text { Niantic }\end{array}$ & $\begin{array}{l}\text { Interactive maps (GPS } \\
\text { locations), 3D Graphic } \\
\text { Design, text, sound, } \\
\text { and 3D animation }\end{array}$ & $\begin{array}{l}\text { Avatar, task, } \\
\text { levels, points, } \\
\text { navigate } \\
\text { location, and } \\
\text { score. }\end{array}$ \\
\hline & & $\begin{array}{l}\text { iButterfly by } \\
\text { Dentsu Inc }\end{array}$ & $\begin{array}{l}\text { 2D Image and } \\
\text { Interactive maps }\end{array}$ & $\begin{array}{l}\text { Navigate } \\
\text { location and } \\
\text { digital objects }\end{array}$ \\
\hline & & Geocaching & Interactive maps & $\begin{array}{l}\text { Navigate } \\
\text { location and } \\
\text { hidden objects }\end{array}$ \\
\hline & & $\begin{array}{l}\text { Ingress by Niantic } \\
\text { and Google }\end{array}$ & $\begin{array}{l}\text { Interactive maps (GPS } \\
\text { coordinates) }\end{array}$ & $\begin{array}{l}\text { Digital objects } \\
\text { and Navigate } \\
\text { location }\end{array}$ \\
\hline 2. & $\begin{array}{l}\text { Montero et } \\
\text { al., (2019) }\end{array}$ & $\begin{array}{l}\text { AR GREP, Designing } \\
\text { and implementing } \\
\text { interactive } \\
\text { and realistic AR } \\
\text { experiences }\end{array}$ & $\begin{array}{l}\text { 3D graphic design, 3D } \\
\text { animation, Image, } \\
\text { video, and audio }\end{array}$ & $\begin{array}{l}\text { Time, Score, } \\
\text { and coins }\end{array}$ \\
\hline
\end{tabular}




\begin{tabular}{|c|c|c|c|c|}
\hline 3. & $\begin{array}{l}\text { Huang et al. } \\
\text { (2017) }\end{array}$ & $\begin{array}{l}\text { Discovery } \\
\text { Augmented Reality } \\
\text { Mobile Gaming } \\
\text { Scheme for } \\
\text { Understanding } \\
\text { Colour } \\
\text { Fundamentals }\end{array}$ & $\begin{array}{l}\text { Text and 2D graphics } \\
\text { design. }\end{array}$ & $\begin{array}{l}\text { Levels, quest, } \\
\text { and rewards }\end{array}$ \\
\hline 4. & $\begin{array}{l}\text { Yigitcanlar, } \\
(2016)\end{array}$ & $\begin{array}{l}\text { Scavenger hunt } \\
\text { games, Augmented } \\
\text { Reality Games for } \\
\text { Increasing Physical } \\
\text { Activity. }\end{array}$ & $\begin{array}{l}\text { Image, video, and } \\
\text { Interactive maps (GPS } \\
\text { coordinates) }\end{array}$ & $\begin{array}{l}\text { Hints, quest, } \\
\text { and navigate } \\
\text { location. }\end{array}$ \\
\hline \multirow[t]{2}{*}{5.} & $\begin{array}{l}\text { Kasapakis \& } \\
\text { Gavalas, } \\
(2017)\end{array}$ & Order Elimination & $\begin{array}{l}\text { Interactive maps, 2D } \\
\text { Graphic Design, and } \\
\text { 2D animation. }\end{array}$ & $\begin{array}{l}\text { Navigate } \\
\text { location, and } \\
\text { points }\end{array}$ \\
\hline & $\begin{array}{l}\text { Kasapakis \& } \\
\text { Gavalas, } \\
(2014)\end{array}$ & ManHunt & $\begin{array}{l}\text { Interactive maps } \\
\text { (Google maps) }\end{array}$ & $\begin{array}{l}\text { Navigate } \\
\text { location }\end{array}$ \\
\hline \multirow[t]{2}{*}{6.} & \multirow[t]{2}{*}{$\begin{array}{l}\text { Dunleavy \& } \\
\text { Dede, (2014) }\end{array}$} & Dino Dig AR Game & $\begin{array}{l}\text { Video, basic interface, } \\
\text { and Interactive maps } \\
\text { (GPS coordinates) }\end{array}$ & $\begin{array}{l}\text { Narrative } \\
\text { storytelling, } \\
\text { quest, badge, } \\
\text { achievement, } \\
\text { and navigate } \\
\text { location. }\end{array}$ \\
\hline & & $\begin{array}{l}\text { Powhatan Village } \\
\text { AR game }\end{array}$ & $\begin{array}{l}\text { Text and 2D graphics } \\
\text { design. }\end{array}$ & $\begin{array}{l}\text { Narrative } \\
\text { storytelling and } \\
\text { score. }\end{array}$ \\
\hline 7. & $\begin{array}{l}\text { Schroeter et } \\
\text { al., (2014) }\end{array}$ & $\begin{array}{l}\text { AR and } \\
\text { Gamification } \\
\text { Concepts to } \\
\text { Reduce Driver } \\
\text { Boredom and Risk- } \\
\text { Taking Behaviours }\end{array}$ & $\begin{array}{l}\text { Texts and graphics } \\
\text { design. }\end{array}$ & $\begin{array}{l}\text { Points and } \\
\text { leaderboards } \\
\text { badges. }\end{array}$ \\
\hline 8. & $\begin{array}{l}\text { Eleftheria et } \\
\text { al., (2013) }\end{array}$ & $\begin{array}{l}\text { AR Game for } \\
\text { Science Education }\end{array}$ & $\begin{array}{l}\text { Applied all the } \\
\text { multimedia elements } \\
\text { such as audio, images, } \\
\text { 2D animation, text, } \\
\text { sound, and video. }\end{array}$ & $\begin{array}{l}\text { Score and } \\
\text { leaderboard }\end{array}$ \\
\hline 9. & $\begin{array}{l}\text { Wang et al., } \\
\text { (2013) }\end{array}$ & $\begin{array}{l}\text { Game-Based AR } \\
\text { Library Instruction } \\
\text { System (GARLIS) in } \\
\text { Elementary } \\
\text { Schools. }\end{array}$ & $\begin{array}{l}\text { Text, 3D graphics } \\
\text { design, and audio. }\end{array}$ & $\begin{array}{l}\text { Narrative } \\
\text { storytelling }\end{array}$ \\
\hline 10. & $\begin{array}{l}\text { ThoughtShas } \\
\text { tra., (2013) }\end{array}$ & $\begin{array}{l}\text { Temple Treasure } \\
\text { Hunt Game, }\end{array}$ & $\begin{array}{l}\text { 2D Graphic Design } \\
\text { and Interactive maps } \\
\text { (GPS coordinates) }\end{array}$ & $\begin{array}{l}\text { Narrative } \\
\text { storytelling, } \\
\text { hints, navigate } \\
\end{array}$ \\
\hline
\end{tabular}




\begin{tabular}{|c|c|c|c|c|}
\hline & & $\begin{array}{l}\text { a whole new } \\
\text { mobile gaming } \\
\text { experience }\end{array}$ & & $\begin{array}{l}\text { location, and } \\
\text { time }\end{array}$ \\
\hline 11. & $\begin{array}{l}\text { Ho et al., } \\
\text { (2012) }\end{array}$ & $\begin{array}{l}\text { AR Intelligence } \\
\text { Matrix Learning- } \\
\text { GoGoBox }\end{array}$ & $\begin{array}{l}\text { Text and 2D graphics } \\
\text { design. }\end{array}$ & $\begin{array}{l}\text { Time, level, and } \\
\text { points }\end{array}$ \\
\hline 12. & $\begin{array}{l}\text { Lindeman \& } \\
\text { Lee, (2012) }\end{array}$ & AR game, GeoBoids & $\begin{array}{l}\text { Video, Interactive } \\
\text { maps (GPS locations), } \\
\text { audio, voice } \\
\text { commands, and 3D } \\
\text { Graphic Design }\end{array}$ & $\begin{array}{l}\text { Navigate } \\
\text { location and } \\
\text { score based on } \\
\text { audio level/ } \\
\text { voice } \\
\text { commands. }\end{array}$ \\
\hline 13. & $\begin{array}{l}\text { Iwata et al., } \\
(2011)\end{array}$ & AR Go & $\begin{array}{l}\text { Text, 2D graphics } \\
\text { design, recording, } \\
\text { information } \\
\text { animation, and sound } \\
\text { effects }\end{array}$ & $\begin{array}{l}\text { Points and } \\
\text { levels }\end{array}$ \\
\hline 14. & $\begin{array}{l}\text { Juan, et al., } \\
\text { (2011) }\end{array}$ & $\begin{array}{l}\text { AR Game for } \\
\text { Endangered Animal } \\
\text { Species }\end{array}$ & 2D Graphic Design & $\begin{array}{l}\text { Basic Game } \\
\text { elements } \\
\text { Points, and } \\
\text { leaderboards } \\
\text { badges. }\end{array}$ \\
\hline 16. & $\begin{array}{l}\text { Herbst, et al., } \\
(2008)\end{array}$ & $\begin{array}{l}\text { TimeWarp: } \\
\text { Interactive Time } \\
\text { Travel with Mobile } \\
\text { AR Game }\end{array}$ & $\begin{array}{l}\text { Text, sound, fully 3D } \\
\text { animation, and } \\
\text { Interactive maps }\end{array}$ & $\begin{array}{l}\text { Digital objects } \\
\text { and navigate } \\
\text { location }\end{array}$ \\
\hline 17. & $\begin{array}{l}\text { Henrysson et } \\
\text { al., (2006) }\end{array}$ & AR Tennis & $\begin{array}{l}\text { 3D modeling (Virtual } \\
\text { court), 2D graphic } \\
\text { design, audio, and } \\
\text { video vibration haptic } \\
\text { feedback }\end{array}$ & $\begin{array}{l}\text { Score and } \\
\text { leaderboard }\end{array}$ \\
\hline
\end{tabular}

Table shows examples of 17 researchers with 21 AR games that have been established for several purposes. In this paper more focus on MAR games design elements and the table shows most of the previous research used 2D graphic design, text, and interactive maps (GPS location) for basic elements. Meanwhile, for game design elements mostly they used to navigate location, points, or coins (money), and score.

\section{Conclusion}

This paper presented the 12 basic elements of mobile augmented reality and 13 games design elements for mobile augmented reality. This review from 17 researchers with $21 \mathrm{AR}$ games found that the most used elements in basic elements and games design elements are 2D graphic design, text, interactive maps (GPS location), navigate location, points or coins, and score.

The significance for all these discoveries is to improve and enhance game design elements in mobile augmented reality. These outcomes can give benefits to MAR game's company, AR 
designers or educators to use appropriate design elements in early phase of development process in creating MAR game design.

\section{Acknowledgement}

I would like to thank my main supervisor, Assoc. Prof. Ts. Dr. Azhar Bin Abd. Jamil for supporting and guiding me in those years. Without his provision, this paper would not have been possible.

Next, my colleagues at Faculty of Arts and Design, Southern University College deserve all the thanks I can give for always supporting and understanding me whenever I had questions.

\section{Corresponding Author}

Fasehah Binti Abdullah, Faculty of Arts and Design at UiTM Shah Alam, Selangor and Faculty of Arts and Design at Southern University College, Johore, Malaysia, fasehah@sc.edu.my

\section{References}

\section{Journal Article}

Antonaci, A., Klemke, R., \& Specht, M. (2015, October). Towards design patterns for augmented reality serious games. In International Conference on Mobile and Contextual Learning (pp. 273-282). Springer, Cham.

Broer, J. (2017). The gamification inventory: an instrument for the qualitative evaluation of gamification and its application to learning management systems.

Cavalcanti, V. C., de Santana Ferreira, M. I., Teichrieb, V., Barioni, R. R., Correia, W. F. M., \& Da Gama, A. E. F. (2019). Usability and effects of text, image and audio feedback on exercise correction during augmented reality based motor rehabilitation. Computers \& Graphics, 85, 100-110.

Dirin, A., \& Laine, T. H. (2018). User experience in mobile augmented reality: emotions, challenges, opportunities and best practices. Computers, 7(2), 33.

Dunleavy, M., \& Dede, C. (2014). Augmented reality teaching and learning. In Handbook of research on educational communications and technology (pp. 735-745). Springer, New York, NY.

Dünser, A., Grasset, R., Seichter, H., \& Billinghurst, M. (2007). Applying HCl principles to AR systems design.

Eishita, F. Z., \& Stanley, K. G. (2018). The impact on player experience in augmented reality outdoor games of different noise models. Entertainment Computing, 27, 137-149.

Eleftheria, C. A., Charikleia, P., Iason, C. G., Athanasios, T., \& Dimitrios, T. (2013). An innovative augmented reality educational platform using Gamification to enhance lifelong learning and cultural education. In IISA 2013 (pp. 1-5). IEEE.

Ferreira-Brito, F., Fialho, M., Virgolino, A., Neves, I., Miranda, A. C., Sousa-Santos, N., \& Santos, O. (2019). Game-based interventions for neuropsychological assessment, training and rehabilitation: Which game-elements to use? A systematic review. Journal of biomedical informatics, 98, 103287.

Gomez, J., Jaccheri, L., Maragoudakis, M., \& Sharma, K. (2019). Digital storytelling for good with Tappetina game. Entertainment Computing, 30, 100297.

Henrysson, A., Billinghurst, M., \& Ollila, M. (2006). AR tennis. In: ACM SIGGRAPH, emerging technologies (p.13) 
Herbst, I., Braun, A. K., McCall, R., \& Broll, W. (2008). TimeWarp: interactive time travel with a mobile mixed reality game. In Proceedings of the 10th international conference on Human computer interaction with mobile devices and services (pp. 235-244).

Ho, P. C., Chung, S. M., \& Lin, Y. H. (2012). Influences on children's visual cognition capabilities through playing 'intelligent matrix' developed by the augmented virtual reality technology. International Journal of Humanities and Arts Computing, 6(1-2), 160-171.

Hsieh, M. C., \& Lin, H. C. K. (2011). A conceptual study for augmented reality e-learning system based on usability evaluation. Communications in Information Science and Management Engineering, 1(8), 5-7.

Huang, Y. W., Wang, C. H., \& Chen, Y. H. (2017). Discovery augmented reality mobile gaming scheme for understanding color fundamentals. In European Conference on Games Based Learning (pp. 944-947). Academic Conferences International Limited.

Iwata, T., Yamabe, T., \& Nakajima, T. (2011). Augmented reality go: extending traditional game play with interactive self-learning support. In 2011 IEEE 17th International Conference on Embedded and Real-Time Computing Systems and Applications (Vol. 1, pp. 105-114). IEEE.

Juan, M. C., Carrizo, M., Abad, F., \& Giménez, M. (2011). Using an augmented reality game to find matching pairs.

Kaklanis, N., Votis, K., \& Tzovaras, D. (2013). Open Touch/Sound Maps: A system to convey street data through haptic and auditory feedback. Computers \& Geosciences, 57, 5967.

Kasapakis, V., \& Gavalas, D. (2014). Blending history and fiction in a pervasive game prototype. In Proceedings of the 13th International Conference on Mobile and Ubiquitous Multimedia (pp. 116-122).

Kasapakis, V., \& Gavalas, D. (2017). Occlusion handling in outdoors augmented reality games. Multimedia Tools and Applications, 76(7), 9829-9854.

Liberati, N. (2018). Phenomenology, pokémon go, and other augmented reality games. Human studies, 41(2), 211-232.

Lindeman, R., \& Lee, G. (2012). GeoBoids: mobile AR for exergaming. In Proceedings of the 13th International Conference of the NZ Chapter of the ACM's Special Interest Group on Human-Computer Interaction (pp. 100-100).

Montero, A., Zarraonandia, T., Diaz, P., \& Aedo, I. (2019). Designing and implementing interactive and realistic augmented reality experiences. Universal Access in the Information Society, 18(1), 49-61.

Noor, N. M., Yusoff, F. H., Yussof, R. L., \& Ismail, M. (2015). The potential use of augmented reality in gamification. In 5th International Conference on Computing and Informatics Proceedings, Istanbul, Turkey (pp. 159-167).

Perkins, C. (2018). 2018 Augmented and Virtual Reality Survey Report. Industry Insights into the Future of $A R / V R, p .4-16, p .18$.

Schroeter, R., Oxtoby, J., \& Johnson, D. (2014). AR and gamification concepts to reduce driver boredom and risk taking behaviours. In Proceedings of the 6th international conference on automotive user interfaces and interactive vehicular applications (pp. 1-8).

Stavropoulos, V., Gomez, R., Mueller, A., Yucel, M., \& Griffiths, M. (2020). User-avatar bond profiles: How do they associate with disordered gaming?. Addictive Behaviors, 103, 106245. 
Wang, Y. S., Chen, C. M., Hong, C. M., \& Tsai, Y. N. (2013). Interactive augmented reality game for enhancing library instruction in elementary schools. In 2013 IEEE 37th Annual Computer Software and Applications Conference Workshops (pp. 391-396). IEEE.

Wee, S. C., \& Choong, W. W. (2019). Gamification: Predicting the effectiveness of variety game design elements to intrinsically motivate users' energy conservation behaviour. Journal of environmental management, 233, 97-106.

Yigitcanlar, T. (2016). Technology and the city: Systems, applications and implications. Routledge.

\section{Online Newspaper Articles}

Statista - The Statistic. (2018). Augmented Reality - Statistics and Facts.

Retrieved from https://www.statista.com/topics/3286/augmented-reality-ar/

ThoughtShastra, (2013). Temple Treasure - A Whole New Mobile Gaming Experience. Retrieved from http://www.thoughtshastra.com/temple-treasure/ on 04.02.2016. 